\title{
Private drinking water supplies: challenges for public health
}

\author{
Jeffrey W.A. Charrois PhD
}

Previously published at www.cmaj.ca

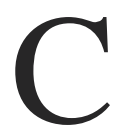
ompared with people in many developing areas throughout the world, Canadians are fortunate to have access to safe drinking water and adequate sanitation. Globally, most diarrheal diseases - responsible for nearly two million deaths a year - can be attributed to unsafe water supplies as well as inadequate sanitation and hygiene. ${ }^{1}$ Most of the deaths are among children in developing nations. Outbreaks of water-borne disease, however, continue to occur regularly in affluent nations. ${ }^{2}$

In the United States, approximately 45 million people obtain their drinking water from domestic wells. ${ }^{3}$ A 2008 review estimated that 19.5 million water-borne illnesses occur each year in the US. ${ }^{4}$ Over the 12 -year study period, $76 \%$ of 183 documented outbreaks and a combined 33\% of estimated water-borne illnesses could be attributed to groundwater systems. ${ }^{4}$ The vulnerability of drinking water to contamination in private wells and the importance of ensuring adequate disinfection and proper maintenance were highlighted in a matched case-control study of children $(<19$ years of age) in Washington: the use of septic systems for disposal of home waste water was associated with both Salmonella (odds ratio [OR] 3.2, 95\% confidence interval [CI] 1.3-7.8) and Escherichia coli $\mathrm{O} 157$ (OR 5.7, 95\% CI 1.2-27.2) infections.

Private water systems in Europe have similar susceptibilities to outbreaks of water-borne disease as those in North America. A review of water-borne infectious intestinal disease in England and Wales from 1992 to 2003 found that the incidence of outbreak among consumers of private water supplies was up to 35 times greater than that among consumers of public water supplies $\left(1830 \mathrm{v} .53\right.$ per million population). ${ }^{6}$ In terms of international best practices, Scotland has developed and adopted an integrated management approach to drinking water that focuses on risk assessment for private supplies; $; .8$ other nations would be well-advised to emulate this initiative.

The primary goal of public drinking water utilities should be to produce and deliver safe, secure drinking water for consumers. For most of 33 million Canadians, the main source of drinking water is from regulated public municipal systems. ${ }^{9}$ However, an estimated three to four million people - about one in every eight Canadians - are served by private supplies, most of which rely on rural groundwater sources. ${ }^{9-11}$ Because this subpopulation, although a substantial number, is fragmented and scattered across the country, it is difficult to quantify and monitor the systems, and efforts to educate consumers about water quality are hindered.

\section{Key points}

- Contamination of private drinking water supplies is common in developed nations.

- In Canada, an estimated three to four million people use private drinking water supplies, most of which originate in rural groundwater sources.

- Contamination by microbial pathogens is the most direct risk, and specific regulations for private drinking water supplies are lacking.

- To mitigate risk, owners of private water supplies must test drinking water regularly for quality, use appropriate treatment (e.g., filters and disinfection) and monitor and maintain the system.

The Guidelines for Canadian drinking water quality, established by the Federal-Provincial-Territorial Committee on Drinking Water, are used by all provinces and territories as the basis for setting enforceable standards or policies for water quality, particularly as it relates to public systems. ${ }^{12}$ The guidelines cover a range of microbiologic, chemical, physical and radiologic health-based maximum acceptable concentrations as well as aesthetic objectives (related to taste, odour and appearance) and operational guidance values (parameters that may affect processes at a treatment plant or within the distribution system). Authority for water quality usually rests with ministries responsible for the environment or health, depending on the province or territory. However, consistent oversight is clearly lacking when it comes to ensuring that the regulatory standards for private water systems are the same as those for public water systems. As part of their mandate to protect public health, provincial ministries of health and regional health authorities provide guidance to owners of private water supplies (and private sewage systems). The guidance is usually provided on request to help private citizens. Owners of private water supplies (i.e., domestic well, cistern or dugout) are legally responsible for the condition and quality of their system. ${ }^{13}$

For this article, peer-reviewed literature on private drinking water supplies was searched using Web of Science (Sci-

From Alberta Innovates-Technology Futures and the Department of Public Health Sciences, School of Public Health, University of Alberta, Edmonton, Alta.

CMAJ 2010. DOI:10.1503/cmaj.090956 
Expanded, 1900-September 2009) and MEDLINE (1950September 2009). A grey literature search of relevant health, environment and agriculture organizations was also performed using Google.

\section{Water-borne illness}

Microbial pathogens pose the greatest risk to the safety of drinking water. Pathogenic organisms capable of causing water-borne illnesses include bacteria (e.g., E. coli, Salmonella, Shigella, Campylobacter and Yersinia), enteric viruses (e.g., noroviruses, rotaviruses and hepatitis $\mathrm{A}$ and $\mathrm{E}$ viruses) and protozoa (e.g., Giardia and Cryptosporidium). Outbreaks of water-borne disease can be caused by weather (e.g., heavy rainfall and spring runoff); improper land application and disposal of manure, sewage sludge or waste water; leaking septic tanks, cesspools, sewers or landfills; failure of water treatment systems; inadequate attention to sanitation in wells; and poor maintenance and treatment practices. ${ }^{14-16}$

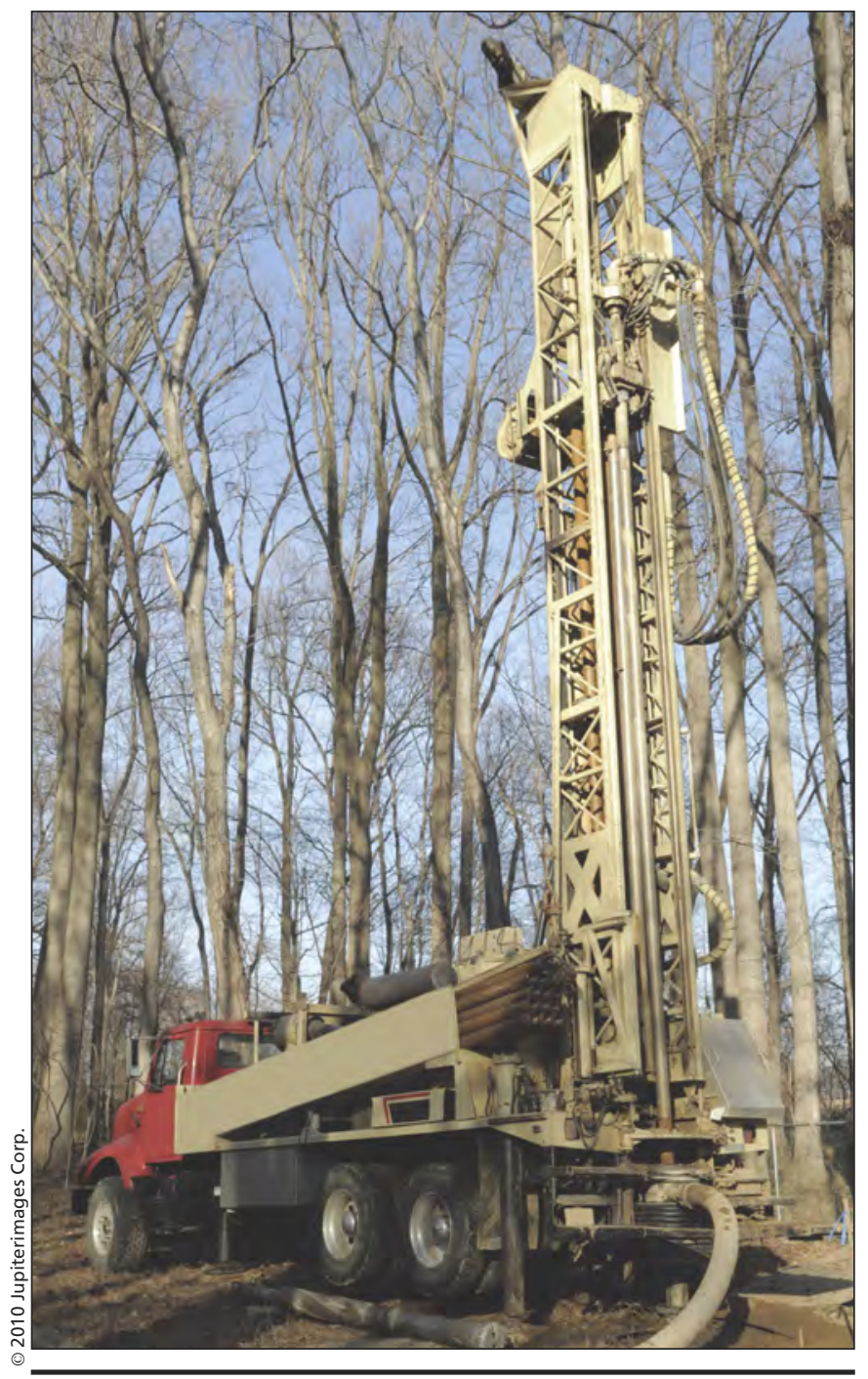

An estimated three to four million Canadians are served by private drinking water supplies, most of which rely on groundwater sources.
A review in Canada of 288 outbreaks of infectious disease related to sources of drinking water over a 27 -year period concluded that two-thirds were related to either semi-private or private systems. ${ }^{15}$ In a 1991-92 survey of 1292 drinking water wells on farmsteads in Ontario, $40 \%$ of the wells were found to contain one or more target contaminants (coliform bacteria, nitrate and select pesticides) at levels above the maximum acceptable concentrations at that time. ${ }^{17}$ Bacterial contamination was the most prevalent, with the maximum level of coliform bacteria being exceeded in $34 \%$ of the wells surveyed. Maximum acceptable concentrations of both E. coli and total coliforms in private drinking water systems are now set at none detectable per $100 \mathrm{~mL} .^{12}$

Vomiting and diarrhea are the most common conditions attributable to water-borne pathogens. Although it is generally considered non-life-threatening and self-limiting in healthy adults, low mortality rates $(3 \%-5 \%)$ have been observed in sensitive subpopulations, including infants and the elderly. ${ }^{18}$ In addition, the burden of acute gastrointestinal illness is significant in Canada. ${ }^{19,20}$ A study in British Columbia showed a rate of 1.3 episodes per person-year $(95 \% \mathrm{CI}$ 1.1-1.4), with an average annual probability of illness developing of $71.6 \%$ (95\% CI 68.0-74.8)..${ }^{19}$ The average duration of acute gastrointestinal disorder was 3.7 days, or 19.2 million days annually. ${ }^{19}$ Another Canadian study showed substantial under-reporting of the illness; for every instance of enteric illness reported in Ontario, the estimated number of patients in the community ranged from 105 to $1389 .{ }^{20}$

\section{Chemical contamination}

Chemical contamination of sources of potable groundwater is common across Canada. Contamination with nitrate at levels above the maximum acceptable concentration frequently occurs in many agricultural regions. ${ }^{21}$ In Saskatchewan, approximately $45 \%$ of the population relies on drinking water from groundwater sources, $70 \%$ of whom use private wells. ${ }^{22}$ A study of 535 wells in that province found that $99.6 \%$ exceeded either an aesthetic or heath-related objective, and in $35 \%$ of those, the maximum acceptable concentrations for one or more health-related parameters (nitrate, arsenic, selenium and coliform bacteria) were exceeded..$^{22}$ Elevated concentrations of naturally occurring metals, such as arsenic, in groundwater can be problematic and are not uncommon in some regions of Canada.

Many studies that monitor pesticides screen for a large number of compounds, which results in many pesticides being detected above analytical detection limits but often below regulatory values. ${ }^{23}$ Analysis for many chemical contaminants, such as pesticides, is expensive, making comprehensive and meaningful monitoring programs difficult. With advances in instrumentation, detection limits are being lowered (now into parts per trillion and parts per quadrillion ranges) and more compounds are inevitably detected. Identification is useful for studies of occurrence, but detection at such negligible levels may draw attention away from the more significant health threats caused by pathogens.

Saskatchewan's Rural Water Quality Advisory Program is 


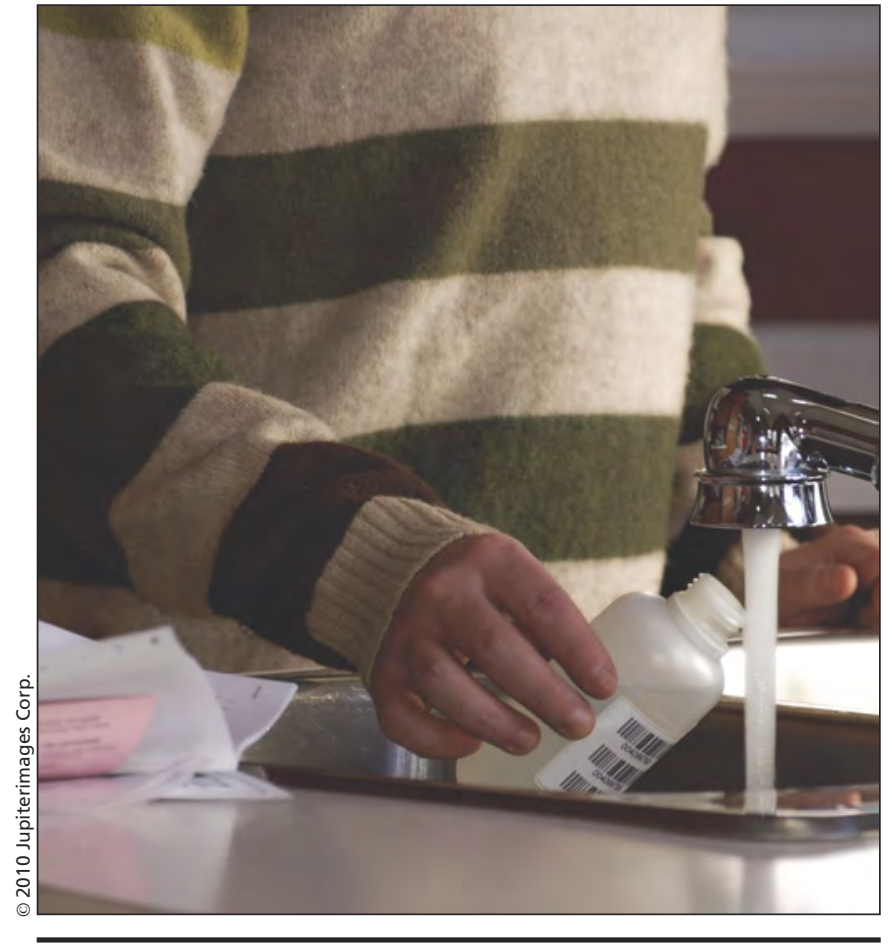

Routine testing of drinking water is essential for ensuring quality and safety.

one of Canada's most innovative, offering full consultative services to anyone in Saskatchewan who relies on a private water supply. For a nominal fee (about $\$ 100$ ), owners receive a comprehensive and focused suite of parameters (major ions, trace metals, nutrients and bacteria) with which to assess the quality of their drinking water. ${ }^{24}$ This program is valuable as a centralized resource for the development of a provincial database on water quality, which would allow priorities to be set based on risk and could serve as a model for other jurisdictions.

\section{Private systems and threats to drinking water}

The perception that private systems - the majority of which come from groundwater in rural and small towns - yield higher water quality than that from municipal sources is common $^{25}$ and unfounded. In one survey, $65 \%$ of Canadian households using nonmunicipal water supplies had not had their water tested by a laboratory within the previous 12 months. ${ }^{10}$ An Ontario study found that only $8 \%$ of private water systems met the current provincial recommendation for frequency of testing. ${ }^{13}$ Suppliers of municipal water, on the other hand, test their water for a variety of parameters daily. Water quality can change at any time. Ontario's Ministry of Health and Long-Term Care recommends proper maintenance and testing of the well water for bacteria three times per year. ${ }^{26}$ Inconvenience and lack of time are reported as key barriers to routine sampling in private wells. ${ }^{25,27}$ Cost, in jurisdictions that do not subsidize routine testing, is an additional obstacle.
The provision of safe, secure drinking water is necessary for protecting public health and requires not only proper technical training but also an understanding of the responsibility this activity carries. Given the lack of routine testing and maintenance reported among private well owners, there appears to be a large gap in public awareness and a lack of educational programs and available resources to improve the public's understanding of potential health threats related to drinking water. Government authorities ought to be financially assisting and better educating owners of private drinking water supplies to ensure that the necessary actions are taken to produce safe, secure drinking water. To remain vigilant against complacency, all Canadian jurisdictions should adopt a culture of continual improvement as it relates to ensuring water quality.

However, the need for owners of private water supplies to take responsibility cannot be overemphasized. They must be willing to pay for water quality testing and to incorporate appropriate processes for water filtration treatment and disinfection. The use of septic and other waste systems must include proper planning, with routine inspection and maintenance to avoid problems such as self-contamination (i.e., when the waste system contaminates the drinking water well). Some excellent resources for owners of private rural water supplies are provided in Appendix 1 (available at www.cmaj .ca/cgi/content/full/cmaj.090956/DC1).

\section{Recommendations for physicians}

Utility operators for public drinking water systems are guardians of public health. In contrast, owners of private supplies typically lack the training and expertise of certified operators. Private supplies can, in many ways, be viewed as miniature public systems; several key principles of risk management used by public utilities can be applied to private systems. Clearly, water-borne disease is the most tangible and direct threat to any drinking water system. However, it can be prevented with appropriate and consistent risk management that includes protecting the drinking water source from contamination, routinely monitoring the water quality, treating the water appropriately (e.g., disinfection and filtration) and undertaking scheduled system maintenance. By understanding these principles, physicians and other health care providers can help increase awareness and educate owners of private water supplies about proactive measures that will protect the health of their family and others who use their water.

Given the substantial burden of disease resulting from water-borne illness as well as the potential for exposure to chemicals in drinking water, physicians (particularly those in rural settings) should enquire about environmental exposures and water supplies when taking a patient's medical history. Reported changes in the quality of well water (e.g., taste, odour, appearance) should serve as an important reminder that trouble is usually preceded by change, ${ }^{2}$ so particular attention should be paid to environmental exposures: they may help pinpoint important triggers causing adverse health outcomes.

The American Academy of Pediatrics recently issued a policy statement and technical report about risks to childen of 
drinking water from private wells. ${ }^{28}$ Key recommendations to physicians and governments include testing of the water every spring for coliforms and nitrates, increased monitoring of the water source in situations where a woman is pregnant or nursing, and additional testing if there are unexplained illnesses or changes in the surrounding environment.

\section{Conclusion}

Safe, secure drinking water is key to ensuring public health. An estimated $13 \%$ of Canadians rely on private drinking water supplies, most of which are served by rural groundwater sources. ${ }^{9-11}$ It is well documented that rural water wells are not tested as often as suggested by experts on water quality, are frequently contaminated with microbial pathogens and chemical contaminants from both natural and anthropogenic sources, and are poorly maintained. ${ }^{11,13,17,22}$ By not routinely testing and evaluating sufficient parameters, owners of private wells may not be fully aware of problems with their water supply ${ }^{10}$ and are therefore unlikely to use appropriate treatment systems. Issues related to the quality of water from private wells are clearly not on the radar of most Canadians. Complacency must be replaced with informed vigilance if systems capable of withstanding challenges to water quality are to be established. ${ }^{2}$

Owners of private systems must take personal responsibility for their water quality, but they need more information and better resources. ${ }^{28}$ Local, provincial and federal governments must develop and deliver innovative awareness and education programs based on evidence that encourage people to take the steps necessary to ensure that their private water systems are safe. It is reasonable to assume that there would be an outcry from consumers in any major Canadian city if they were routinely supplied with tap water of the quality seen in many rural private water supplies. Gaps in rural public health surveillance ${ }^{20}$ and a lack of clear and consistent standards and policies as well as of evidence-based educational, research and training programs to support owners of private water systems ${ }^{28}$ are critical shortcomings that need to be better addressed in Canada.

\section{This article has been peer reviewed.}

Competing interests: None declared.

Acknowledgements: The author thanks Dr. Steve E. Hrudey (University of Alberta) and Dr. Jim Davies (Alberta Innovates-Technology Futures) for their review and comments on this article as well as Ms. Karen Emde (Alberta Health Services) and Dr. Donald Reid (Alberta Environment) for thoughtful discussions.

\section{REFERENCES}

1. WHO (World Health Organization). Water sanitation and hygiene links to health Geneva (Switzerland): The Organization; 2004. Available: www.who.int /water_sanitation_health/publications/facts2004/en (accessed 2010 Jan. 7).

2. Hrudey SE, Hrudey EJ. Safe drinking water - lessons from recent outbreaks in affluent nations. London (UK): IWA Publishing; 2004.

3. Focazio MJ, Tipton D, Dunkle Shapiro S, et al. The chemical quality of self-supplied domestic well water in the United States. Ground Water Monit Remediat 2006 26:92-104
4. Reynolds KA, Mena KD, Gerba CP. Risk of waterborne illness via drinking water in the United States. Rev Environ Contam Toxicol 2008;192:117-58.

5. Denno DM, Keene WE, Hutter CM, et al. Tri-county comprehensive assessment of risk factors for sporadic reportable bacterial enteric infection in children. $J$ Infect Dis 2009;199:467-76.

6. Smith A, Reacher M, Smerdon W, et al. Outbreaks of waterborne infectious intestinal disease in England and Wales, 1992-2003. Epidemiol Infect 2006;134:1141-9.

7. Scottish Executive. Private water supplies: technical manual. Edinburgh (Scotland): The Executive; 2006. Available: www.privatewatersupplies.gov.uk/private _water/66.html?pMenuID=1\&pElementID=2 (accessed 2010 Jan. 7).

8. Lilly A, Edwards AC, McMaster M. Microbiological risk assessment source protection for private water supplies: validation study. Aberdeen (UK): Macaulay Institute; 2008. Available: www.scotland.gov.uk/Publications/2008/03/27135305/0 (accessed 2010 Jan 7).

9. Statistics Canada. Domestic water use: the relevance of rurality in quantity used and perceived quality. Rural and Small Town Canada Analysis Bulletin. Cat. no. 21-006-X, 2009; 7:1-31. Available:www.statcan.gc.ca/bsolc/olc-cel/olc-cel ?catno=21-006-X\&CHROPG=1\&lang=eng (accessed 2009 Dec. 7).

10. Households and the environment. Ottawa (ON): Statistics Canada; 2007. Cat. no. 11526-X:1-102. Available: www.statcan.gc.ca/pub/11-526-x/11-526-x2009001-eng .htm (accessed 2010 Jan. 7).

11. Corkal D, Schutzman WC, Hilliard CR. Rural water safety from the source to the on-farm tap. J Toxicol Environ Health A 2004;67:1619-42.

12. Federal-Provincial-Territorial Committee on Drinking Water. Guidelines for Canadian drinking water quality - summary table. Ottawa (ON): Health Canada; 2008. Available: www.hc-sc.gc.ca/ewh-semt/pubs/water-eau/sum_guide-res _recom/index-eng.php (accessed 2010 Jan. 7).

13. Jones AQ, Dewey CE, Doré K, et al. Public perception of drinking water: a postal survey of residents with private water supplies. BMC Public Health 2006;6:94.

14. Pedley S, Howard G. The public health implications of microbiological contamination of groundwater. Q J Eng Geol 1997;30:179-88.

15. Schuster CJ, Ellis AG, Robertson WJ, et al. Infectious disease outbreaks related to drinking water in Canada, 1974-2001. Can J Public Health 2005;96:254-8.

16. Nichols G, Lane C, Asgari N, et al. Rainfall and outbreaks of drinking water related disease in England and Wales. J Water Health 2009;7:1-8.

17. Goss MJ, Barry DAJ, Rudolph DL. Contamination in Ontario farmstead domestic wells and its association with agriculture: 1 . Results from drinking water wells. $J$ Contam Hydrol 1998;32:267-93.

18. Canadian drinking water guidelines development process. Ottawa (ON): Health Canada; 1999. Available: www.hc-sc.gc.ca/ewh-semt/pubs/water-eau/development -elaboration/index-eng.php (accessed 2010 Jan. 7).

19. Thomas MK, Majowicz SE, MacDougall L, et al. Population distribution and burden of acute gastrointestinal illness in British Columbia, Canada. BMC Public Health 2006;6:307.

20. Majowicz SE, Edge VL, Fazil A, et al. Estimating the under-reporting rate of infectious gastrointestinal illness in Ontario. Can J Public Health 2005;96:178-81.

21. Fitzgerald D, Chanasyk DS, Neilson RD, et al. Farm well water quality in Alberta Water Qual Res J Can 2001;36:565-88.

22. Sketchell J, Shaheen N. Ground water quality in rural Saskatchewan - emerging issues for drinking water. Maintaining drinking water - lessons from the prairies and beyond. Proceedings of the CWWA's/Health Canada's 9th National Drinking Water Conference. 2000 May 16-18. Regina (SK).

23. Prince Edward Island Department of Environment, Energy and Forestry. PEI groundwater pesticide monitoring program. Charlottetown (PEI): The Department; 2009. Available: www.gov.pe.ca/envengfor/index.php3?number $=1023896 \&$ lang=E (accessed 2010 Jan. 7).

24. Saskatchewan Watershed Authority. Monitoring and assessment: rural water quality advisory program. Regina (SK): The Authority. Available: www.swa.ca/Stewardship /AssessmentMonitoring/Default.asp (accessed 2010 Jan. 7).

25. Jones AQ, Dewey CE, Doré K, et al. Public perception of drinking water from private water supplies: focus group analyses. BMC Public Health 2005;5:129.

26. Ontario Ministry of Health and Long-Term Care. Water safety: putting your well water to the test. Toronto $(\mathrm{ON})$ : The Ministry; 2009. Available: www.health.gov.on .ca/english/public/pub/watersafe/watersafe welltest.html (accessed $2010 \mathrm{Jan} .7$ ).

27. Hexemer AM, Pintar K, Bird TM, et al. An investigation of bacteriological and chemical water quality and the barriers to private well water sampling in a Southwestern Ontario community. J Water Health 2008:6:521-5.

28. Committee on Environmental Health and Committee on Infectious Diseases. Drinking water from private wells and risks to children. Pediatrics 2009;123:1599-605.

Correspondence to: Dr. Jeffrey W.A. Charrois, Alberta InnovatesTechnology Futures, Environmental Management and Health, Hwy 16A-75 St., PO Bag 4000, Vegreville AB T9C 1T4;

jeffrey.charrois@albertainnovates.caorjwc@ualberta.ca 